\title{
Preparation of Polyaniline/polyvinylalcohol nanocomposite and study its characterization after exposure to Laser Irradiation.
}

${ }^{1}$ A.B El- Bially., ${ }^{2}$ A.A.Shabaka, ${ }^{1}$ S.Abd.ElMongy., ${ }^{1}$ N.A.M.Shahin., ${ }^{1}$ R. Kamal and ${ }^{1}$ F.I. Barakat.

${ }^{1}$ Department of Spectroscopy Physics, Faculty of Girls for Art, Science and Education, Ain Shams University.

${ }^{2}$ Department of Spectroscopy, Physics Division, National Research Center, Giza, 12622, Egypt.

\begin{abstract}
The present work reports(PANI/PVA) nanocomposite with different irradiation laser times were prepared. The result of transmission electron microscope (TEM) indicated that the morphology of PANI/PVA nanocomposite has a regular spherical shape. The molecular structures had been studied using Fourier Transform Infrared Spectrometer (FTIR) and the spectra of PANI/PVA nanocomposite were formed in emeraldine salt form, which consists of benzonid and quinoid. .

The conductivity measurements show that the initially electrically insulating PVA/AniHCl blend has been transformed into the electrically conducting PVA/PANI nanocomposites where the conductivity increases by increasing irradiation times. The conduction mechanism had been explained
\end{abstract}

Key words:PANI/PVA nanocomposites,TEM,FTIR and Dc electrical conductivity.

\section{Introudication}

Nanoscale materials, as a set of substances, where at least one dimension is less than approximately 100 nanometers,a approximately 100,000 times smaller than the diameter of a human hair,(Surowiak et al.,2001: and Lines et al., 2008). Conducting polymers are polymers containing an extended $\pi$ - conjugated system, made up of overlap of singly occupied p orbitals in the backbone of the polymer chain (Weder, 2005:Gospodinova and Terlemzyan, ,1998: Schreiberet al., 1995:Detsriet al.,2009: and Pron and Rannou,2002). Although conducting polymers possess a relatively large number of delocalized $\pi$-electrons, a fairly large energy gap exists between the valence band and the conducting band (greater than $1 \mathrm{eV}$ ). Thus these polymers are considered to be semiconducting, at best.

Corresponding author: Fawzya_sc@yahoo.com 
These polymers must be doped (usually to the number of $\pi$-electrons) in order to render the polymers truly conducting.

Nanocomposites are a special class of materials originating from suitable combinations of two or more such nanoparticles or nanosized objects in some suitable technique, resulting in materials having unique physical properties and wide application potential in diverse areas that can be formed into a useful object (Wang et al.,2007: and Wang and Shi, 2007). Novel properties of nanocomposites can be derived from the successful combination of the individual characteristics of parent constituents into a single material. To exploit the full potential of the technological applications of the nanomaterials, it is thus extremely important to endow them with good processability (Song et al.,2004: and Caruso,2001) . Polyaniline (PANI) is one of the most important conducting polymers, it's easy preparation and doping process, environmental stability, and potential use as electro chromic device, as sensor and as corrosion protecting paint. These properties turned (PANI) attractive to use in solar cells, displays, lightweight battery electrodes, electromagnetic shielding devices, and anticorrosion coatings. Also Polyaniline have better electrical, electrochemical, physical, optical properties and good stability than other conducting polymers (MacDiarmidet al., (1998) . Polyvinyl alcohol (PVA), a colorless, water-soluble synthetic resin employed principally in textiles and paper treatment. The excellent chemical resistance and physical properties of PVA resins have led to broad industrial use .Moreover, it has high electrical resistivity $(3.1-3.8) \times 10^{7} \Omega$, leading to the extremely excellent antistatic properties of the film. (PVA) is used in sizing agents that give greater strength to textile yarns and make paper more resistant to oils and greases.

\section{2- Materials and Methods}

\subsection{Chemicals}

Aniline hydrochloride (AniHCl,$\left(\mathrm{C}_{6} \mathrm{H}_{8} \mathrm{CLN}\right)$, molecular weight $\left.=129.59 \mathrm{~g} / \mathrm{mol}\right)$ (Oxford) and deionized water.

Polyvinyl-Alcohol $\left(\mathrm{C}_{6} \mathrm{H}_{7} \mathrm{~N}\right)$ of molecular weight 6000 with minimum assay $99.5 \%$ purchased from Mallinckrott.

\subsection{Experimental procedure}

The (PVA) solution was first prepared by dissolving (PVA) powder ( $5 \mathrm{~g})$ in deionized water $(100 \mathrm{ml})$ and exposed to continuous stirring for 3 hours. AniHCl powder $(1.5 \mathrm{~g})$ 
was added to the (PVA) solution at room temperature and continuously stirred for approximately three hour until a clear solution was obtained. The solution was paused in Petri dish and left to dry in air at room temperature to obtain the desired films. the films were then stripped from the dish to ensure complete dissolution.

The PVA/AniHCl blend films were cut into several pieces to facilitate the exposure to laser irradiation using (CW-Diode -807 at power $1500 \mathrm{~mW}$ ) at different irradiation time of $(3,6,9,12$ and 15$)$ min.

\section{Result and discussion}

\subsection{Fourier transforms infrared spectra of PANI/PVA composite before and} after irradiation:-

The FTIR spectra of the PANI/PVA composite before exposure to irradiation is measured in the range from 4000- $400 \mathrm{~cm}^{-1}$ as illustrated in Figure (1). The empirical formula corresponding to polyaniline is $\mathrm{C}_{24} \mathrm{H}_{20} \mathrm{~N}_{4}$, The broad absorption peak at 3350 $\mathrm{cm}^{-1}$ is due to stretching vibration of hydrogen bonded $(\mathrm{O}-\mathrm{H})$ of the absorbed water. This reflected the formation of hydrogen bonds between alcohol molecules and PANI chains (Zhenget al.,1997). The two bands appeared at $2942 \mathrm{~cm}^{-1}$ and $2917 \mathrm{~cm}^{-1}$ are related to the asymmetric aromatic and symmetric aliphatic $\mathrm{C}-\mathrm{H}$ stretching vibration respectively. The strong absorption band at $1735 \mathrm{~cm}^{-1}$ may be ascribed to the $\mathrm{C}=\mathrm{N}$ stretching vibration. The band at $1651 \mathrm{~cm}^{-1}$ is corresponded to quinonoid $(\mathrm{N}=\mathrm{Q}=\mathrm{N})$ stretching vibrations, and the band at $1436 \mathrm{~cm}^{-1}$ corresponding to benzenoid ( N-B-N) stretching vibrations respectively (Shukla et al., 2010:Xia et al., 2005: and Yu et al., 2006). The appearance of these two bands indicates the formation of polyaniline (PANI) (Gupta et al., 2009: Roy et al., 1998: and Vivekanandan et al., 2011).

By comparing PANI/PVA composite and PANI /PVA nanocomposite at different irradiation times $(3,6,9,12$ and 15$)$ min., we observed that the two absorption bands of $\mathrm{N}=\mathrm{Q}=\mathrm{N}$ and $\mathrm{B}-\mathrm{N}-\mathrm{B}$, for the quinonoid and the benzenoid structures at $1651 \mathrm{~cm}^{-1}$ and $1436 \mathrm{~cm}^{-1}$ shifted to higher wavenumber $(1659,1664,1668,1668,1669) \mathrm{cm}^{-1}$ and $(1439,1442,1442,1442,1443) \mathrm{cm}^{-1}$ with increasing irradiation time to $(3,6,9,12$ and 15) min, respectively.( Aleahmad et al., 2011and Sangamesha et al., 2014) The appearance of this band confirms that, the (PANI) contain the conducting emeraldine salt phase. 


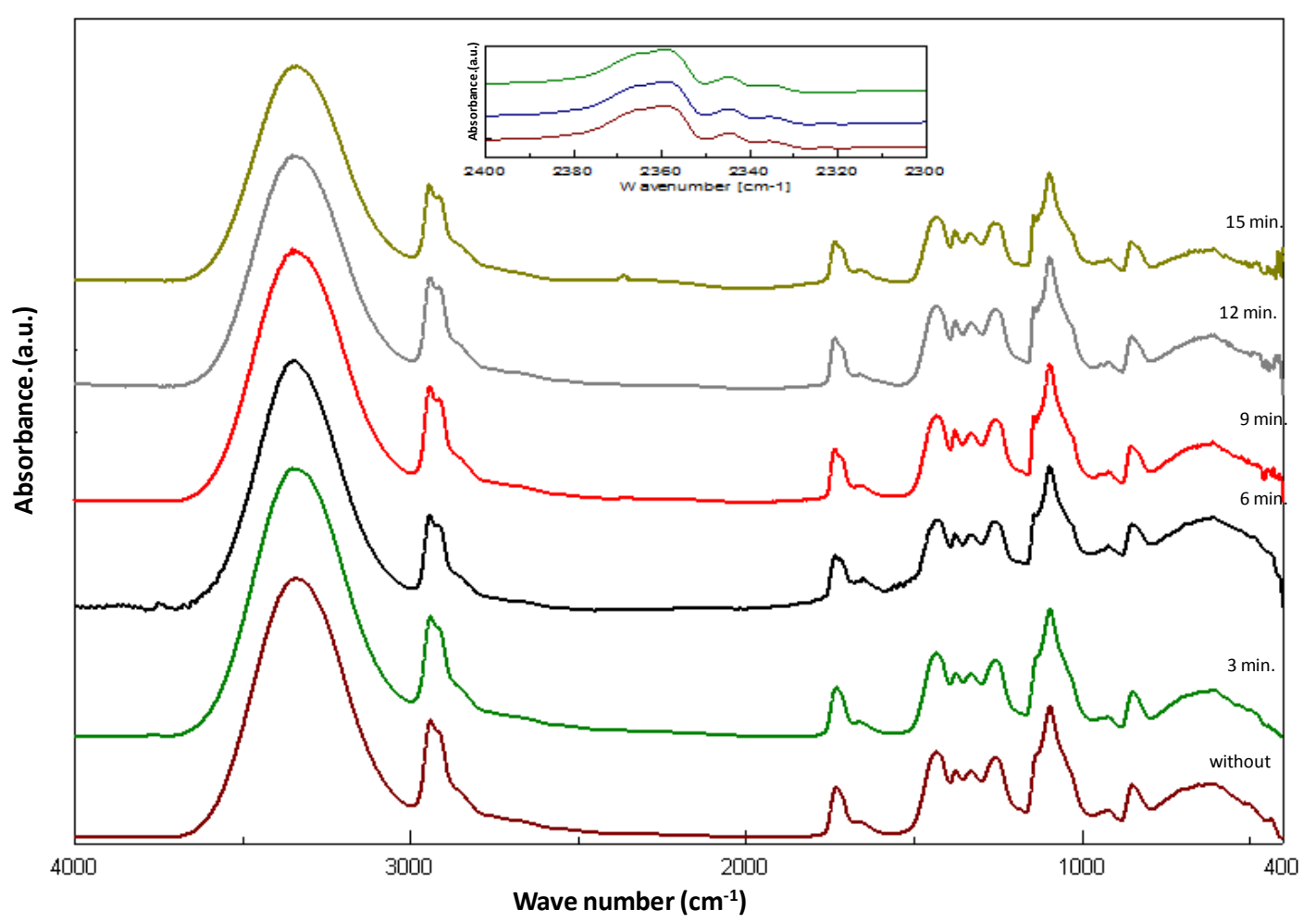

Figure (1): The infrared spectrum of PANI/PVA nano composite at different irradiation times $(3,6,9,12$ and 15$)$ min.

From the figure it can be noted that, the stretching vibration of hydrogen bond $(\mathrm{O}-\mathrm{H})$ of the absorbed water of PANI/PVA composite which appeared at wavenumber $\left(3350 \mathrm{~cm}^{-1}\right)$ are shifted to higher wavenumber $(3365,3361,3354,3354,3357) \mathrm{cm}^{-1}$ at irradiation times (3, 6, 9, 12, and 15) min., respectively. (Yu et al.,2011). Also from the figure it can be shown that, the new bands appeared in the FTIR spectrum of PANI /PVA nanocomposite at $\left(2360,2361\right.$ and 2363) $\mathrm{cm}^{-1}$ at irradiation times $(9,12$ and 15) min., respectively. These band are due to the stretching vibration of $\mathrm{CH}_{2}$ group for carboxylic acid in the (PANI) .The interchain hydrogen bonding between amine and imine nitrogen sites separate (PANI) chains which has been proposed to be a driving force in the formation of the (PANI) nanocomposite (yang and, Haixiwu 2009: Laslauet al., 2009: Zhang et al., 2004: Fan et al., 1996: Laslau.et al., 2009:and Dinget al., 2008). The molecular interactions, such as hydrogen bonds, and Van-der-Waals forces are powerful driving forces for the PANI/PVA composite.

\subsection{Transmission Electron Microscope (TEM) of PANI/PVA Nanocomposite by laser Irradiation.}

(TEM) images and histogram of the particle size distribution of PANI/PVA nanocomposite exposed at different irradiation time (3, 6, 9, 12 and 15) min.,are shown in Figure (2:a-e). From these images, it is clear that the morphology of 

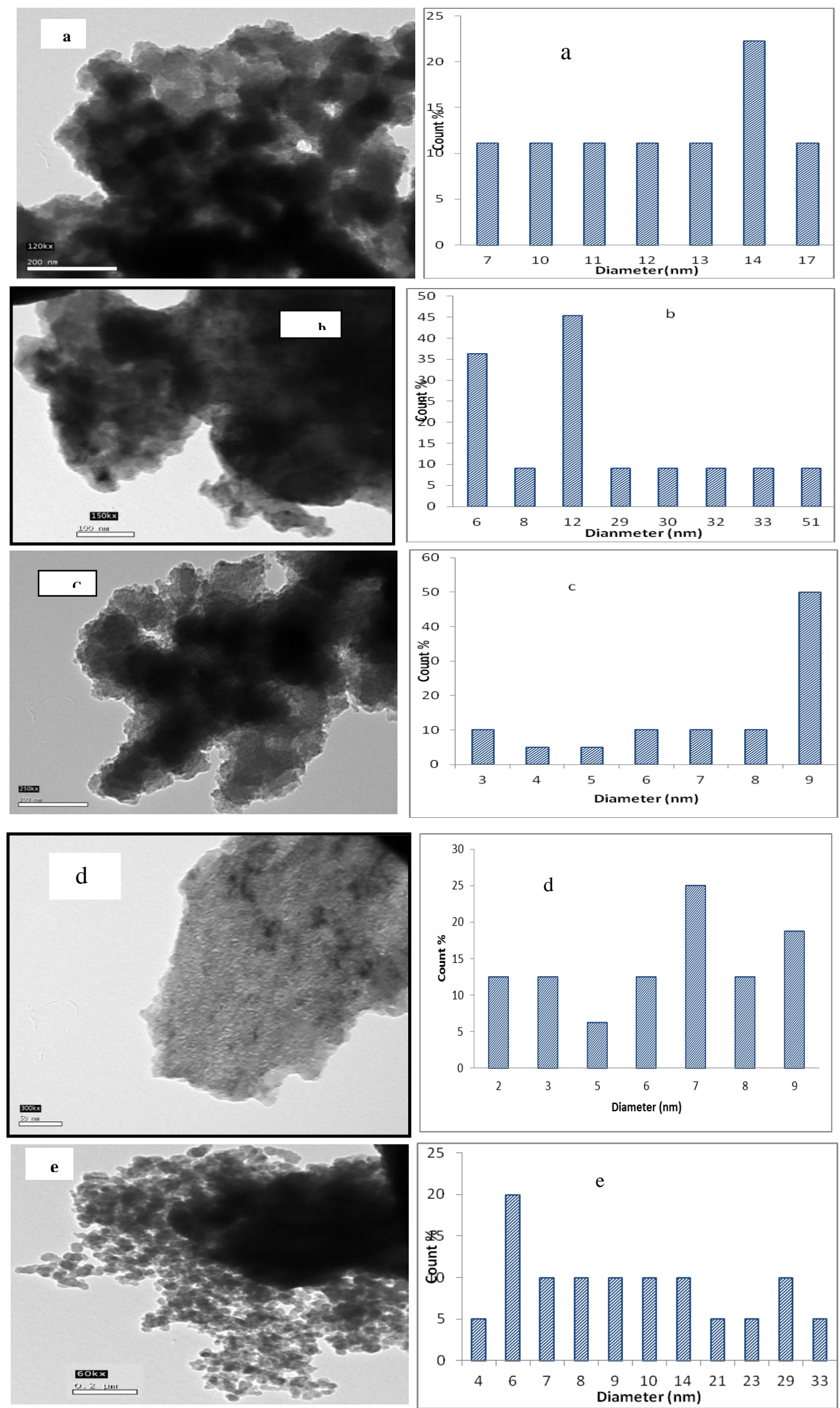

Figure (2:a-e): TEM imageand the histogram of the particle size distribution of PANI/PVA nanocomposite with irradiation time at (3, 6, 9, 12 and 15) min. 
PANI/PVA nanocomposite has regular spherical shape (Gandopadhyayet al.,2001) in the nanometer size range $(6-14 \mathrm{~nm})$.The nanocomposite formed with distinct distribution. It can be observed that the grain size decrease from $(14,12,9$, 7and 6$)$ $\mathrm{nm}$ as the irradiation time increase from $(3,6,9,12$ and 15$)$ min., respectively, as shown in Figure(2:a-e).

\section{3:Electrical conductivity of PANI/PVA composite before and after irradiation} time.

The DC electrical conductivity was calculated at room temperature and listed in Table (1). From this table, it is clear that, DC conductivity of PANI/PVA composite is $1.85 \times 10^{-8} \Omega^{-1} \cdot \mathrm{cm}^{-1}$ and increase with increasing irradiation times to $\left(7.9 \times 10^{-7}\right.$, $4.6 \times 10^{-6}, 4.3 \times 10^{-5}, 3.1 \times 10^{-4}$ and $4.7 \times 10^{-4}$.) $\Omega^{-1} . \mathrm{cm}^{-1}$ at $(3,6,9,12$ and 15$) \mathrm{min}$, respectively. The conductivity values of PANI/PVA nanocomposite increased with increasing irradiation time from 3 to $15 \mathrm{~min}$., The conductivity of conjugated polymers critically depends on its conjugation length.

Table (1): The electrical conductivity of PANI/PVA composite before and after different irradiation time, at room temperature.

\begin{tabular}{|c|c|}
\hline Time (min) & Conductivity $\left(\mathbf{\Omega}^{-\mathbf{1}} \mathbf{. c m} \mathbf{- 1}^{\mathbf{1}}\right)$ \\
\hline Without irradiation & $1.85 \times 10^{-8}$ \\
\hline $3 \min$ & $7.9 \times 10^{-7}$ \\
\hline $6 \min$ & $4.6 \times 10^{-6}$ \\
\hline $9 \min$ & $4.3 \times 10^{-5}$ \\
\hline $12 \min$ & $3.1 \times 10^{-4}$ \\
\hline $15 \min$ & $4.7 \times 10^{-4}$ \\
\hline
\end{tabular}


The dependence of DC electrical conductivity $\left(\sigma_{\mathrm{Dc}}\right)$ on the reciprocal of absolute temperature $\frac{1000}{T}$ for PANI/PVA before and after irradiation were shown in Figure (3). From this figure, it is clear that, the conductivity for PANI/PVA composite increased with increasing the irradiation times, at (3, 6, 9, 12 and 15 ) min.This increase can be assigned to the cooperation of two factors, the increase in the mobility of charge carriers and the increase in the rate of charge carrier generation (Zaidi et al., 1995: and Shihub and Gould, 1995). The increase in conductivity indicates that there is a transition from $\mathrm{PVA} / \mathrm{AniHCl}$ dielectric polymer blend to PVA/PANI conducting nanocomposites following irradiation.

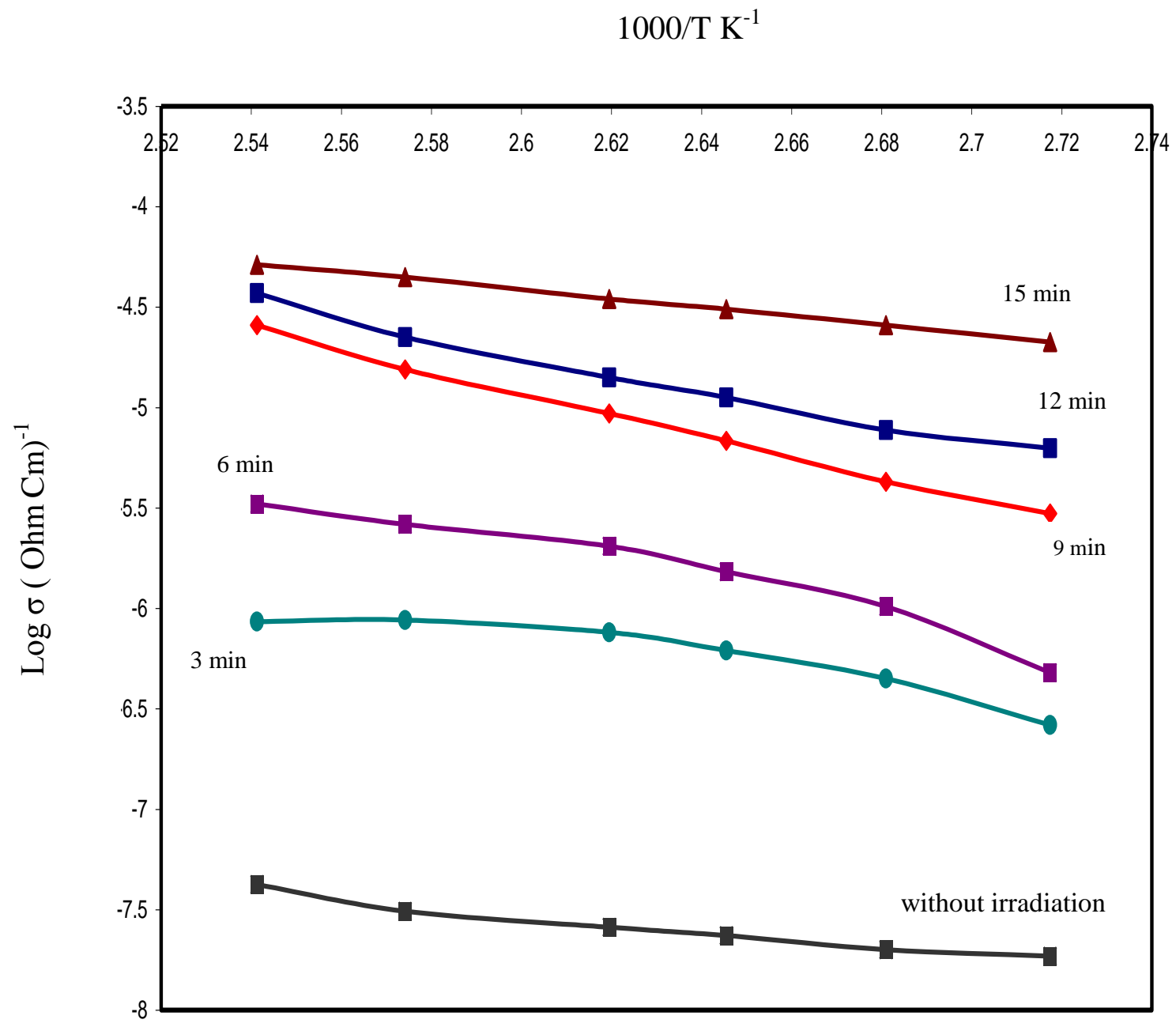

Figure (3): The variation of the DC conductivity with $1000 / \mathrm{T}$ as a function of PANI/PVAnanocomposite at different irradiation times (3,6,9,12 and 15) mints. 
Also, we have to choose the model that will best fit our result. The temperature dependence of the electrical conductivity of PANI/PVA composite with PANI /PVA nanocomposite at different irradiation times are shown in Figure (4). The figure shows linearity, thus, it can be suggested that the conduction mechanism in the investigated samples is the tunneling mechanism (Zeller, 1972) and (Ortonet al., 1982).

$$
\mathrm{T}^{-1 / 2}(\mathrm{~K})^{-1 / 2}
$$

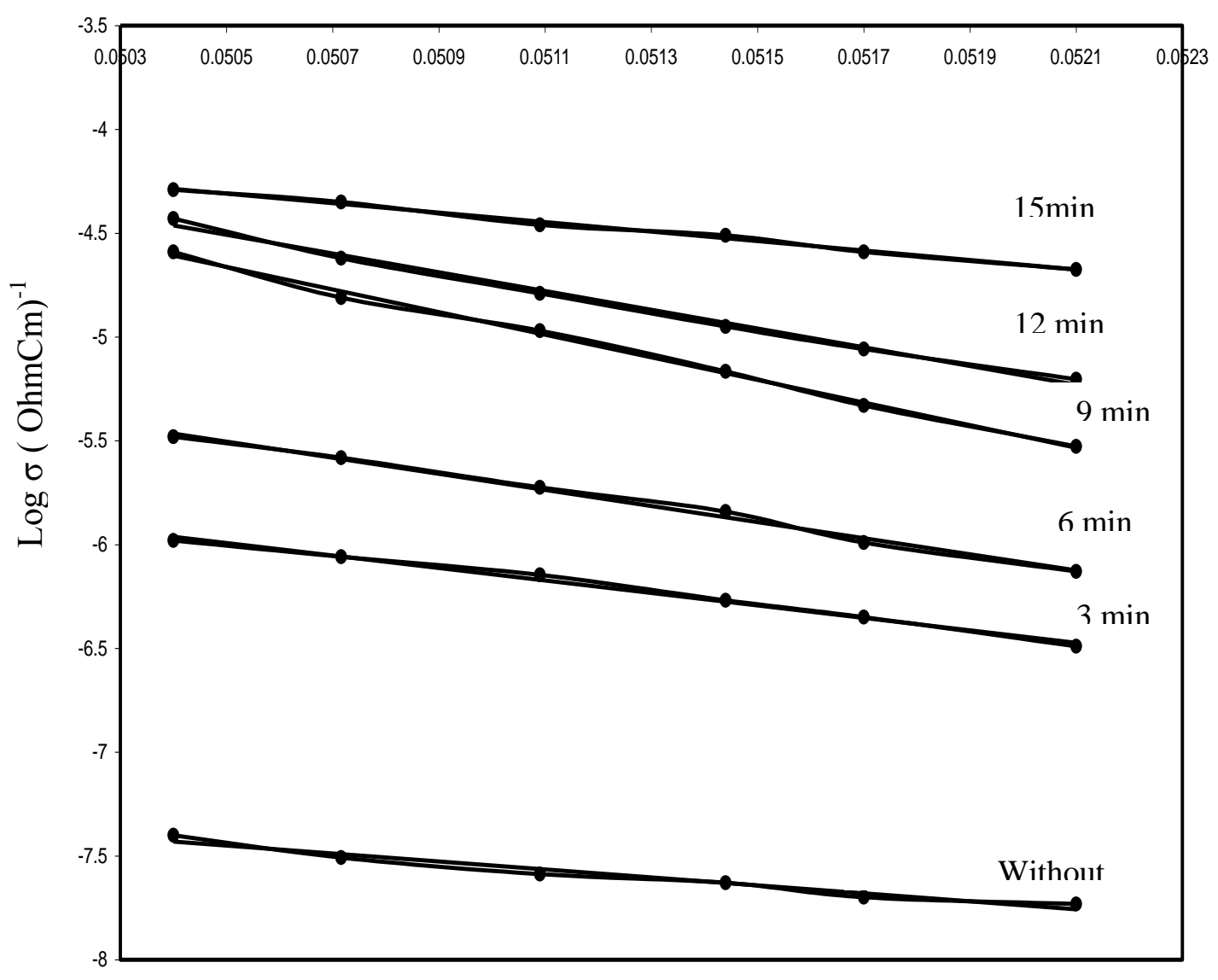

Figure (4):The temperature dependence of electrical conductivity for PANI/PVAnanocomposite at different irradiation times, $(3,6,9,12$ and 15) mints.based on the tunneling mechanism. 


\section{Conclusion}

For FTIR the PANI/PVA nanocomposite, with increasing irradiation time, some vibrational bands are shifted to higher wavenumbers. Due to the H-bonding interaction between polyaniline chains and hydrochloric acid, and hydrogen bonding between the amine and imine nitrogen sites in the PANI chain. FTIR data revealed that, the spectra of PANI/PVA nanocomposite were formed in emeraldine salt form, which consists of benzonid and quinoid. From the (TEM) results, the particle size of PANI/PVA nanocomposite was decrease from 14 to $6 \mathrm{~nm}$ as the irradiation time increased from 3 to $15 \mathrm{~min}$, and PANI/PVA nanocomposite has the spherical morphologies are still preserved. The increase in conductivity indicates that there is a transition from PVA/AniHCl dielectric polymer blend to PVA/PANI conducting nanocomposites following irradiation.

\section{Refrences}

Aleahmad M.,Taleghani H.G. and Isazadeh H., Synthetic Metals 161, 990-995(2011)

Caruso F., Advenced. Mater. 13 ,11(2001).

Detsri E., Dubas S. T.,Metals J., Materials and Minerals .19, 39(2009).

Ding H.,Shen J.,Wan M., and Chen Z., Macromolecular Chemical Physics. 209, 864 (2008).

Fan Q., and Ng L. M., Vac J.. Science. Technology. A., 14, 1326 (1996).

Gandopadhyay R, A.De, Ghosh.G,Synthetic Metals. 12, 21-313 (2001)

Gospodinova N., Terlemzyan L.,Science. progress. Polymer. 23, 1443 (1998).

K.Gupta, G. Chakraborty P.C. Jana and A.K.Meikap Journal of Physical Sciences. 13,251-260 (2009) .

Laslau C.,Zujovic Z. D., and Travas-Sejdic J., Macromolecular Rapid Communication. 30,1663 (2009).

Laslau C.,Zujovic Z. D., Zhang L. , Bowmaker G. A., and Sejdic J. T., materials chemistry. 21, 954 (2009).

Lines M. G., Alloys J. and Compounds .449,242 (2008).

MacDiarmid A. G., Epstein A. J., Faraday Discussions .88,317 (1989).

Orton J.W. , Powell M., J.Rep. Progress Physical. 43 , 1263 (1980).

Pron A.,Rannou P., Progress in Polymer. Science. 27,135 (2002).

Roy R., Aryya A. Bhattach,Sen S .K., and Sen S., Physices. Status. Solidi.165, 245 (1998). 
Sangamesha M.A., Pushpalatha K., Shekar G.L.,Indian Journal of Advances in Chemical Science 2(3), 223-227(2014).

Schreiber M.,Tenelsen K.,Vojta T., J. Luminescence.521, 66-67 (1995).

Shihub S.I. and Gould R.D., Thin Solid Films.245, 187 (1995).

Shukla S.K., Bhradvaja A., Tiwari A., PillaSrikant,P. G.K. and Dubey G.C., Advanced materials. letters1(2) .129-134 (2010).

Song C., Wang D., Lin Y., Hu Z., Gu G.,Fu X., Nanotechnology. 15, 962 (2004).

Surowiak Z., Molecular and Quantum Acoustics. 22, 239 (2001).

Vivekanandan J.,Ponnusamy V., Mahudeshwaran A., and Vijayanand P.S., Archives. Applied Science Research., 3, 6,147-153 (2011).

Wang S.,Shi G., Materials. Chemistry and Physics. 102, 255 (2007).

Wang Z., Chen J.,Xue X., Hu Y., Materials Research Bulletin. 240, 2211 (2007).

Weder C., Chemical Communication. 5378 (2005).

Yu X., Fan H.,.Wang H, Zhao N., Zhang X., and Xu J., Materials letters 65,28122815 (2011).

Xia H.,Narayanan J., Cheng D., Xiao C., Liu X., and Chan H.S. O., J. Physical Chemistry.109, 12677 (2005).

Yang Y., Haixiwu C., polymer testing .28, 371-377 (2009) .

Yu Y., Zhihuai S., Chen S.,Bian C., Chen W., andXue G., Langmuir. 22, 3899 (2006).

Zaidi S.A., Baynon J., and Steel B., Thin Solid films. 256, 120 (1995).

Zeller H.R., physical Review Letters. 28, 1452 (1972).

Zhang L., Long Y.,Chen Z., and Wan M., Advanced.Functional.Materials.14, 693 (2004).

Zheng W., Angelopoulos M., Epstein A. J., and MacDiamid A. G., Macromolecules.30 2953,(1997). 


\section{ملخص باللغة العربية}

" تحضير متراكبات البولى أنلين النانومترية و دراسة خصائصها بعد تعريضها لأثعة الليزر "

\section{أسماء المشاركين فى البحث}

\section{وعناوينهم}

1-أ.د عايدة بدر البيلى أستاذ الأطياف / قسم الفيزياء كلية البنات جامعة عين شمس 2-أ.د على على شبكة أستاذ الأطياف/قسم الطيف شعبة البحوث الفيزيائية المركز القومي للبحوث

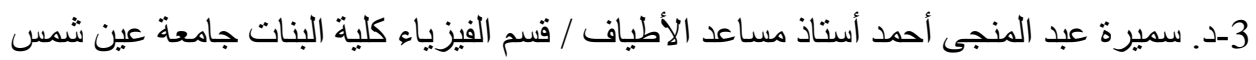

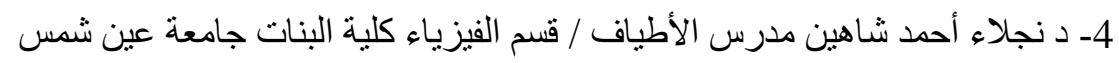

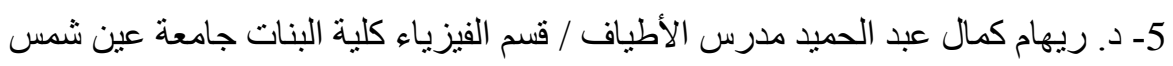

هناك دائما حاجة لمو اد جديدة أخف وزنا و أقل تكلفة و أكثر تتو عـا متقدمــ لتلبية مطالب المستهلكين الصناعيين.

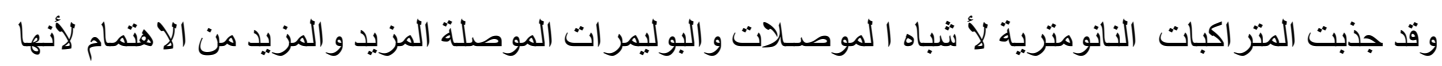

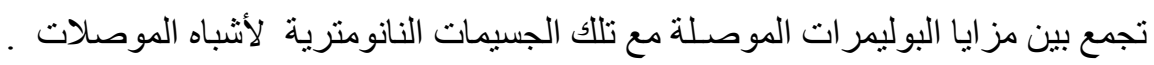
و تكمن اهمية هذه الأنواع من المتر اكبات النانومنرية ليس فقط في خواصها الفيزيائية و الكيميائية الجديدة

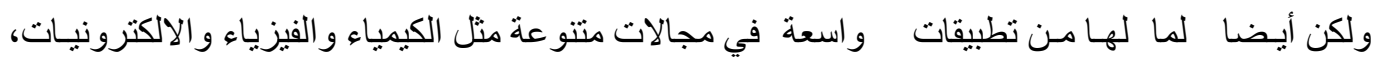
و البصريات ،و العلوم الطبية الحيوية ، و علم المو اد.

يتناول هذا البحث تحضير سلسلة من متر اكبات البولي أنلين مع البولي فينيل الكحول لتكوين مجموعة من في

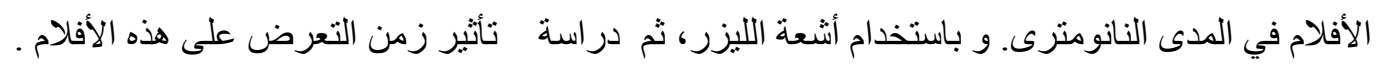

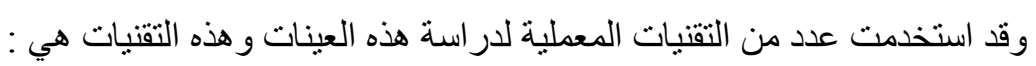
الميكروسكوب الالكتروني لدر اسة مورفولوجي العينة ، ثم توصيف المواد النانومترية باستخدام مطياف الأشعة

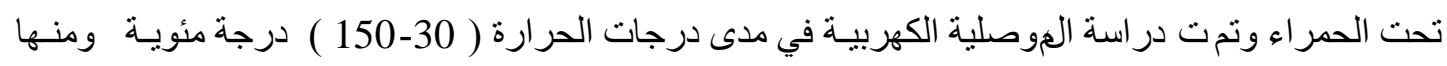

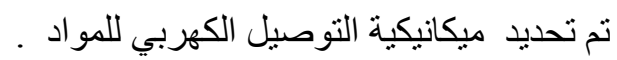

• ومن دراسة أطباف امنصاص الأشعة تحت الحمراء أتضح أن منر اكبات البولي أنلين مع البولي فينيل الكحول يتكون esalt (Es) emeraldine salt

• من نتائج الميكروسكوب الإلكترونى النافذ أن جزيئات منر ا كبات البولي أنلين مع البولي فينيل الكحول

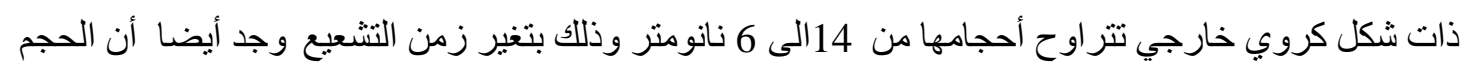
الحبيبي للمو اد النانومتريه يقل بزيادة زمن التشعيع .

• وقد اشتملت الدراسة أيضا علي قياس الموصلية الكهربية (DC conductivity) لكل العينات في مدى درجات الحرارة من (30-150) درجة مئوية وق أظهرت النتائج زيادة في التوصيلية بزيادة درجات الحر ارة مع زيادة

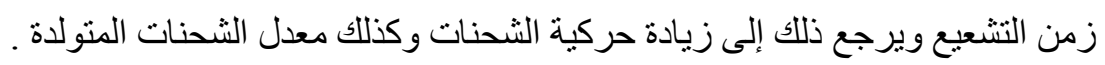


Tunneling وقد تم حساب طاقة التنشيط اللازمة لعملية التوصيل ، وقد دلت النتائج على أن آلية التوصيل تتبع . model 